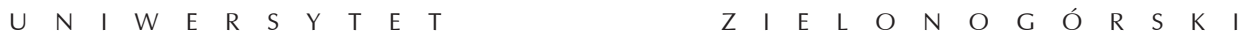

Przegląd Narodowościowy - Review of Nationalities

Jews $\mathrm{nr}$ 6/2016

DOI: $10.1515 / p n-2016-0005$

ISSN 2084-848X (print) ISSN 2543-9391 (on-line)

Henryk Cimek*

\title{
Jewish problem in the Polish Communist Party
}

Keywords: Jews, the Communist Party of Poland, separatism, The Second Republic of Poland sŁowa kıuczowe: Żydzi, Komunistyczna Partia Polski, separatyzm, II Rzeczypospolita Polska

In the being reborn Poland after World War I, Jews formed their own parties, which forced the criterion of nationality or they joined the Polish, Ukrainian and Belarusian parties. This was especially true about the revolutionary parties, mainly the Polish Communist Party (KPP), the Communist Party of Western Ukraine, the Communist Party of Western Belarus and the Polish Communist Youth Union. The presence of Jews in the KPP was associated mainly with the position of the Communist International (CI), according to which in a given country only one communist party could exist. Although the Polish Communists did not express opposition to this principle, part of the Jews for a long time showed a desire to create their own Jewish Communist Party subordinated only to CI.

According to official data of the first two censuses, conducted in Poland on 30 September 1921 and 9 December 1931, the number of Jews increased from 2110448 people (7.8\%) to 2732600 people $(8.6 \%)^{1}$. On the other hand, Janusz Żarnowski says that the percentage of Jews decreased from 10.5\% to $9.8 \%$. Jerzy Tomaszewski shares a similar view ${ }^{2}$. Apart from non-precision of quoted censuses, it can be said that the distribution of Jews in the Second Republic was uneven. Most of them lived in the former Polish Kingdom. The second place in this respect was occupied by former Galicia, while the percentage of Jews on the lands of the former

\footnotetext{
* Professor, Faculty of Political Sciences Academy of Humanities in Pułtusk.

1 Rocznik Statystyki Rzeczypospolitej Polskiej 1925/1926, Warszawa 1927, p. 26; Mały Rocznik Statystyczny 1939., Warszawa 1939, pp. 22-23.

2 J. Żarnowski, Społeczeństwo Drugiej Rzeczypospolitej 1918-1939, Warszawa 1973, p. 389; Najnowsze dzieje Żydów w Polsce w zarysie (do 1950 r.), J. Tomaszewski (edit.), Warszawa 1993, p. 159.
} 
Prussian partition was small (approx. 1\%). They lived mainly in large cities and towns ${ }^{3}$. At the end of 1931, most of them were in the cities of the provinces Polesie $(48.6 \%)$ and Nowogródek (40.3\%). As for the village, most Jews lived in the Lublin province, where they represented $40 \%$ of the total Jewish population in the area 4 .

Socialist thought among Jews on the Polish soil began to take shape in the last decade of the nineteenth century. The socialists of Jewish origin originally belonged to the Polish socialist parties. The first Jewish socialist party was founded in 1897 . It was the General Jewish Workers' Union (Bund), which worked in every part of Russia, including the Polish Kingdom. In Galicia, the Jewish Social-Democratic Party was founded in 1905, and in 1920, it merged with the Bund ${ }^{5}$, which called for the solution of the Jewish problem in the way of building the socialist system in Poland with the national-cultural autonomy for the Jews. On the other hand, the Jewish Social-Democratic Party Workers of Zion (Poale Zion), which was established in the Polish Kingdom in 1905, tried to combine socialist and Zionist ideas. Zionists (Jewish nationalists) exposed the national identity of the Jews and in perspective sought to create their own state in Palestine, and as a closer target some of them called for the establishment of the Polish-Jewish state ${ }^{6}$. The Jewish Socialist Workers' Party United (Ferajnigte), created in November 1918, also tried to combine socialist and Zionist ideas.

After founding of the Communist Polish Workers Party (KPRP) on 16 December 1918 and the creation of the Communist International (CI) on 2-6 March 1919 there were polarizations of views in the mentioned Jewish workers' parties. The leftist groups joined the Polish Communist Party and formed the communist Jewish organizations. The split in the Poale Zion occurred in July 1920, and as a result Poale Zion Right and Poale Zion - Left were created. The latter participated in the deliberations of the $3^{\text {rd }}$ CI Congress (22 June-12 July 1921). This party was ready to join the Polish Communist Party, but wanted to retain autonomy in Jewish affairs. From October 1921, a communist faction - Jewish Communist Union of Poale Zion in Poale Zion - Left existed, which after its exclusion from the party in November 1921 joined the Polish Communist Party. Among others, Saul Amsterdam-Henrykowski and Alfred Lampe were at its head. The splinter group of Ferajnigte, the weakest of these Jewish parties joined the Polish Communist Party in August 1921.

Ideological ferment took place also in the Bund, where the Communist faction was formed. In January 1922, it evolved into a Jewish Communist Union of Workers

3 Ibidem, p. 162.

$4 \quad M R S$ 1939..., p. 23; E. Horoch, KPP $w$ województwie lubelskim w latach 1918-1938, Lublin 1993, p. 81; Z. Urbański, Mniejszości narodowe w Polsce, Wyd. II, Warszawa 1933, pp. 221 and following.

5 J. Holzer, Mozaika polityczna Drugiej Rzeczypospolitej, Warszawa 1974, p. 271.

6 A. Czubiński, Dzieje najnowsze Polski do roku 1945, Poznań 1994, pp. 202 and following. 
in Poland (Kombund). Because on 12 June 1922 the Executive Committee of CI declared Kombund in Poland as a part of CI, as an organization distinct from the Polish Communist Party, Kombund did not join the Polish Communist Party occurred until mid-February 1923.

In addition to belonging to their own communist organizations, Jews also joined directly the Polish Communist Party, which in 1919 created the Jewish Department. It became a part of the Central Committee of the party. After the decision to merge Kombund with the Polish Communist Party, a temporary Central Bureau of Jewish Sections was established. It consisted of the Jewish Department and appointed activists of Kombund. In 1923, this office was renamed to the Central Jewish Bureau (CBŻ), enjoying a high degree of autonomy in the Polish Communist Party. After the unification of Kombund with the Polish Communist Party, in March-April 1923 also the Cukunft Communist Youth Organization (Komcukunft), founded on 2 February 1922, merged with the Union of Communist Youth (ZMK) in Poland, officially created on 17 March 1922 in Warsaw ${ }^{7}$.

The consequence of the above-described process was rapid increase in the proportion of Jews in KPRP and ZMK in Poland. The number of Jews in the organizations is, however, difficult to determine. In August 1923, KPRP had more than 5,500 members, of which probably about $50 \%$ were Jews. There were provincial organizations almost exclusively Jewish or with significant participation of Jews, such as the Regional Committee of KPRP Lublin in 1923 with $76.3 \%$ and in 1925 with $82.4 \%{ }^{8}$. The increase in the percentage of Jews was even higher in ZMK, which after joining Komcukunft had about 7 thousand members (before the arrests), in which there were at least $60 \%$ of Jews.

Jews also belonged, but not in such large numbers, to created after the Second Congress of KPRP (19 September - 2 October 1923) an autonomous organization of KPRP: Communist Party of Western Ukraine (KPZU) and the Communist Party of Western Belarus (KPZB). In these parties there were mostly peasants, but for example in KPZU in 1924 Jews constituted 13.3\% of the members in the KPZB 18-20\%, while in ZMK of Western Ukraine 25\% in $1926^{9}$.

The Central Committee of KPRP (from 1 February 1925 KPP) and Central Committee (KC) of ZMK noticed the disadvantages resulting from such a large number of Jews in their party. They proposed, among others, polonization of KPRP, and closer

7 See more: H. Cimek, Żydzi w ruchu komunistycznym w Polsce w latach 1918-1937, „Polityka i Społeczeństwo" 9/2012, Rzeszów 2012, pp. 31 and following.

8 E. Horoch, KPP w województwie lubelskim..., pp. 83-85.

9 Archives of New Files (AAN), KPZU, 165/V-10, s. 1; ibidem, KPZB, 163/II/1, p. 1; L. Krzemień: Związek Młodzieży Komunistycznej w Polsce. Pierwsze dziesięciolecie (1918-1928), Warszawa 1972, p. 222. 
linking the activity of CBŻ with the whole party. The Jews, who belonged to the city and small town organizations, often did not know the Polish language, which intensified separatist tendencies ${ }^{10}$. Partial liquidation of autonomy of the Central Jewish Bureau occurred only at the beginning of 1929.

The number of Jews in the Polish Communist Party can be gathered only for some years, more raw data on the ethnic composition is available for ZMK (from February 1930 the Polish Communist Union of Youth KZMP). In ZMK, the percentage of Jews in the years 1926-1931 remained roughly at the same high level (43.0 - 44.2\%). The whole ZMK, thus together with ZMK of Western Belarus and Western Ukraine had 3,700 members in 1926 and 4900 members in 1931. Starting from 1931 the percentage of Jews in KPP and KZMP diminished in favor of the peasants. This was mainly the consequence of outlawing the Belarusian Peasant-Workers Hromada (1925-1927), the Union of the Peasant Left 'Self-Help' (1928-1931) and Sel-Rob Union (1928-1932). Part of members of these parties, with no possibility of legal action, joined the KPP, KPZB, KPZU and KZMP. Among others, the reluctance of Jews to work in the rural areas slowed down the process ${ }^{11}$.

The entire KPP reached the highest number of its members in March 1933 - 17 800, including 4000 in CPWB and 4600 in CPWU, while KZMP in October 1933 had 15000 members, including the 3800 from KZM ZB and 3900 from KZM ZU. Later there was a downward trend in the development of the communist movement in Poland. In 1933, the number of Jews in the KPP (without KPZB and KPZU) was approximately $26 \%$. However, in KZMP since February 1930 to October 1933 the number of Jews fell from $51 \%$ to $32 \%$. Poles occupied the second place, respectively $19 \%$ and $33 \%$. The disparities in individual districts, however, were very large ${ }^{12}$.

The percentage of Jews was generally higher in the authorities of KPP and KZMP. Among 19 members of the Central Committee of KPP in January 1936 there were 11 Poles, 6 Jews (31.6\%), 1 Belarusian and 1 Ukrainian. In the KC KPZB there were at that time $40.0 \%$ of the Jews, and in the KC KPZU $-42.9 \%$. There were even more Jews among the district active members of KPP in $1935-53.8 \%$. According to the National Secretariat of the Central Committee of the KPP at the beginning of 1936 Jews had too large proportion in the active members of the management of the whole party and in

10 Rossijskij Gosudarstwiennyj Archiw Socyalno-Politiczeskoj Istorii, Komunistyczna Międzynarodówka Młodzieży, f. 533, op. 10, d. 2265, p. 108. Sprawozd. Sekretariatu KC ZMK za XII 1924 i 1 I-15 II 1925.

11 H. Cimek: Legalne chłopskie partie rewolucyjne w Drugiej Rzeczypospolitej, Białystok 1988, pp. 98 and following; idem, Żydzi w ruchu komunistycznym w Polsce..., pp. 35-36; idem, Mniejszości narodowe w ruchu rewolucyjnym w II Rzeczypospolitej, Rzeszów 2011, pp. 122 and following.

12 Ibidem, pp. 146 and following. 
KZMP - 54.0\%, whereas in 1933 including the KPP and KZMP 32800 members of more than 8400 members were Jews - about $26.0 \%{ }^{13}$.

KPP authorities were not satisfied with the national composition of its active members, especially in the fight for the Popular Front (1935-1937), when the first Communist International and KPP exposed the struggle against fascism and the defense of independence of Poland against the expansion of Nazi Germany. Communists coming from ethnic minorities were often difficult to convince to the second postulate. It concerned especially the Ukrainian communists. At the end of 1936, the ethnic composition of KPP authorities changed even more against the number of Poles ${ }^{14}$.

Minorities, mainly Jews, to a lesser extent Belarusians and Ukrainians, prevailed in the KPP and KZMP. There were about $30.0 \%$ of Poles in both organizations, while in the society of the Second Republic about $69.0 \%$. The role of Jews in the communist movement in Poland is not easy to evaluate. Some activists of Jewish origin made a creative contribution to the development of political thought in the KPP, among others on issues of strategy of revolution of parliamentarianism (Adolf Warszawski-Warski, Maksymilian Horwitz-Walecki and others). Jewish communists, but not all, however were, like the Ukrainian and Belarusian communists, manifesting the tendencies to separatism and nationalism, in spite of the current IC idea of proletarian internationalism. Initially, they manifested themselves in the efforts to create a Jewish communist party in Poland, separate from KPP. Then a part of the Jewish communists sought to maintain autonomy within the KPP. The dominant position of the Jews in the authorities of the KPP and KZMP intensified the negative attitude of the communists to the Second Republic, although some communists of Jewish origin perceived the need to defend its independence. However, there were those who exposed the interests of national minorities at the expense of the Polish question and evinced a distinct aversion to work among the peasants ${ }^{15}$.

\section{Bibliography}

Cimek H., Legalne chłopskie partie rewolucyjne w Drugiej Rzeczypospolitej, Białystok 1988.

Cimek H., Żydzi w ruchu komunistycznym w Polsce w latach 1918-1937, „Polityka i Społeczeństwo” 9/2012, Rzeszów 2012.

Czubiński A., Dzieje najnowsze Polski do roku 1945. Poznań 1994.

Holzer J., Mozaika polityczna Drugiej Rzeczypospolitej, Warszawa 1974.

Horoch E., KPP w województwie lubelskim w latach 1918-1938, Lublin 1993.

13 AAN, MK, 151/VII-1, vol. 21, pp. 11-13; H. Cimek, Mniejszości narodowe w ruchu rewolucyjnym..., p. 158.

14 More: ibidem, pp. 144 and following.

15 Ibidem, p. 126; P. Śpiewak, Żydokomuna. Interpretacje historyczne, Warszawa 2012, pp. 149 and following. 
Mały Rocznik Statystyczny 1939, Warszawa 1939.

Najnowsze dzieje Żydów w Polsce w zarysie (do 1950 r.), J. Tomaszewski (edit..), Warszawa 1993.

Rocznik Statystyki Rzeczypospolitej Polskiej 1925/1926, Warszawa 1927.

Rossijskij Gosudarstwiennyj Archiw Socyalno-Politiczeskoj Istorii, Komunistyczna Międzynarodówka Młodzieży.

Śpiewak P., Żydokomuna. Interpretacje historyczne, Warszawa 2012.

Urbański Z., Mniejszości narodowe w Polsce, Wyd. II. Warszawa 1933.

Żarnowski J., Społeczeństwo Drugiej Rzeczypospolitej 1918-1939, Warszawa 1973.

\section{Jewish problem in the Polish Communist Party}

ABSTRACT

Jews accounted for approx. 8-10\% of the population of the Second Republic and in the communist movement (Polish Communist Party and Polish Communist Youth Union) the rate was approx. 30\%, while in subsequent years it much fluctuated. The percentage of Jews was the highest in the authorities of the party and in the KZMP. This had a negative impact on the position of the KPP on many issues, especially in its relation to the Second Republic.

\section{Problem żydowski w Komunistycznej Partii Polski}

STRESZCZENIE

Żydzi stanowili ok. 8-10\% ludności II Rzeczypospolitej, a w ruchu komunistycznym (Komunistyczna Partia Polski i Komunistyczny Związek Młodzieży Polski) odsetek ten wynosił ok. 30\%, przy czym w poszczególnych latach znacznie on się wahał. Odsetek Żydów był najwyższy we władzach partii i w KZMP. Odbijało się to negatywnie na stanowisku KPP w wielu kwestiach, zwłaszcza na jej stosunku do II Rzeczypospolitej. 